\title{
Carcinoembryonic antigen and carbohydrate antigen 19-9 are prognostic predictors of colorectal cancer with unresectable liver metastasis
}

\author{
YOSHINOBU MITSUYAMA, HIROAKI SHIBA, KOICHIRO HARUKI, YUKI FUJIWARA, \\ KENEI FURUKAWA, TOMONORI IIDA, TAKENORI HAYASHI, MASAICHI OGAWA, \\ YUICHI ISHIDA, TAKEYUKI MISAWA, HIDEYUKI KASHIWAGI and KATSUHIKO YANAGA
}

Department of Surgery, Jikei University School of Medicine, Tokyo 105-8461, Japan

Received August 12,2011; Accepted November 17, 2011

DOI: $10.3892 / \mathrm{ol} .2012 .574$

\begin{abstract}
No evidence currently exists to demonstrate the prognostic value of serum carcinoembryonic antigen (CEA) and carbohydrate antigen 19-9 (CA19-9) in patients with unresectable colorectal cancer liver metastases (CRLM). Therefore, we retrospectively investigated the correlation between serum CEA and CA19-9 levels and overall survival in patients with unresectable CRLM. The study involved 40 patients who were diagnosed with unresectable CRLM between March 2000 and August 2010 at Jikei University Hospital, Japan. We retrospectively investigated the correlation between patient characteristics, including serum CEA and CA19-9 levels, and overall survival using univariate and multivariate analyses. In the univariate analysis, the absence of primary tumor resection $(\mathrm{p}=0.0161)$, the absence of systemic chemotherapy $(\mathrm{p}=0.0119)$, serum CEA $\geq 100 \mathrm{ng} / \mathrm{ml}(\mathrm{p}=0.0148)$ and CA19-9 $\geq 100 \mathrm{U} / \mathrm{ml}$ $(p<0.0001)$ were significant predictors of poor survival. In the multivariate analysis, the absence of systemic chemotherapy $(\mathrm{p}=0.0356)$, serum $\mathrm{CEA} \geq 100 \mathrm{ng} / \mathrm{ml}(\mathrm{p}=0.0079)$ and CA19-9 $\geq 100 \mathrm{U} / \mathrm{ml}(\mathrm{p}=0.0002)$ were independent predictors. Serum CEA and CA19-9 levels are therefore independent prognostic predictors of survival in patients with unresectable CRLM.
\end{abstract}

\section{Introduction}

Colorectal cancer is the third leading cause of cancer and the fourth leading cause of cancer mortality worldwide (1). Liver metastasis is one of the most significant prognostic factors in patients with colorectal cancer, and approximately $25 \%$ of patients present with liver metastases at the time of initial diagnosis of colorectal cancer. A further $40-50 \%$ of patients

Correspondence to: Dr Yuki Fujiwara, Jikei University School of Medicine, 3-25-8, Nishi-Shinbashi, Minato-ku, Tokyo 105-8461, Japan

E-mail: sheetan@jikei.ac.jp

Key words: colorectal cancer, liver metastasis, carcicoembryonic antigen, carbohydrate antigen 19-9, prognosis develop colorectal liver metastases (CRLM) within 3 years of resection of the primary tumor (2). Hepatic resection is the most effective and potentially curative therapy for CRLM (3-6). The 5-year overall survival rate following hepatic resection is reported to range from 28 to $50 \%$ (7-11). Liver resection, however, can only be performed in approximately $10-20 \%$ of patients with CRLM due to unresectable multiple and bilobar metastasis (12). The survival rate of patients who do not undergo resection is poor and does not exceed $2 \%$ at 5 years $(13,14)$. Therefore, the assessment of prognostic predictors is essential in the management of patients with unresectable CRLM.

Carcinoembryonic antigen (CEA) has been widely accepted as a significant prognostic factor $(15,16)$ and an indicator of recurrence or therapeutic effect in patients with colorectal cancer (17-21). Carbohydrate antigen 19-9 (CA19-9) is another tumor marker for gastrointestinal cancers $(22,23)$, and certain authors have proposed that it has prognostic significance in cases of colorectal cancer (24-26). With regard to CRLM, the prognostic value of serum CEA and CA19-9 levels remains controversial, and specifically, no such study has been carried out in patients with unresectable liver metastasis.

The purpose of this study was to clarify the clinical significance of serum CEA and CA19-9 levels with regard to the diagnosis of unresectable CRLM.

\section{Patients and methods}

Patients. Between March 2000 and August 2010, 55 patients were diagnosed with unresectable liver metastasis from colorectal cancer at the Department of Surgery, Jikei University Hospital, Tokyo, Japan. Of the 55 patients, 15 patients were excluded from the study; 6 due to concomitant microwave coagulation or radiofrequency ablation therapy, 4 due to lack of data, and 5 who were lost to follow-up, leaving a remaining 40 patients who participated in this study. This study was approved by the Ethics Committee of Jikei University school of Medicine.

Methods. Prior to 2003, we determined that 5 or more bilobar metastases of the liver were unresectable according to the definition of $\mathrm{H} 3$ liver metastasis by the Japanese classification 
Table I. Univariate analysis of overall survival following the diagnosis of unresectable colorectal cancer liver metastases.

\begin{tabular}{|c|c|c|c|}
\hline \multirow[t]{2}{*}{ Characteristics } & \multirow[t]{2}{*}{$\mathrm{N}$} & \multicolumn{2}{|c|}{ Overall survival } \\
\hline & & Median (years) & p-value \\
\hline \multicolumn{4}{|l|}{ Age (years) } \\
\hline$<60$ & 10 & 1.18 & 0.8451 \\
\hline$\geq 60$ & 30 & 0.66 & \\
\hline \multicolumn{4}{|l|}{ Gender } \\
\hline Male & 30 & 1.18 & 0.7956 \\
\hline Female & 10 & 0.74 & \\
\hline \multicolumn{4}{|l|}{ Timing of tumor } \\
\hline Synchronous & 26 & 0.74 & 0.0853 \\
\hline Metachronous & 14 & 1.65 & \\
\hline \multicolumn{4}{|c|}{ Primary cancer site } \\
\hline Colon & 23 & 1.46 & 0.5902 \\
\hline Rectum & 17 & 0.90 & \\
\hline \multicolumn{4}{|c|}{ Primary tumor resection } \\
\hline Yes & 32 & 1.43 & 0.0161 \\
\hline No & 8 & 0.48 & \\
\hline \multicolumn{4}{|c|}{ Primary tumor stage } \\
\hline II, III & 11 & 1.59 & 0.1227 \\
\hline IV & 29 & 0.78 & \\
\hline \multicolumn{4}{|c|}{ Extrahepatic disease } \\
\hline Yes & 24 & 1.10 & 0.4308 \\
\hline No & 16 & 0.88 & \\
\hline \multicolumn{4}{|c|}{ Chemotherapy for CRLM } \\
\hline Yes & 34 & 1.18 & 0.0119 \\
\hline No & 6 & 0.51 & \\
\hline \multicolumn{4}{|l|}{ CEA (ng/ml) } \\
\hline$<100$ & 22 & 1.55 & 0.0148 \\
\hline$\geq 100$ & 18 & 0.62 & \\
\hline \multicolumn{4}{|l|}{ CA19-9 (U/ml) } \\
\hline$<100$ & 30 & 1.55 & $<0.0001$ \\
\hline$\geq 100$ & 10 & 0.62 & \\
\hline
\end{tabular}

CRLM, colorectal cancer with liver metastases; CEA, carcinoembryonic antigen; CA19-9, carbohydrate antigen 19-9.

of colorectal carcinoma (27). Since 2004, we determined that cases with insufficient hepatic reserve or remnant liver volume were unresectable. During both the periods studied, cases with poor performance status and metastasis to other organs (excluding the lungs, local recurrence or para-aortic lymph node metastasis) were generally diagnosed as unresectable. In cases of unresectable liver metastasis, systemic chemotherapy was administered based on the performance status. Prior to 2003, we generally selected leucovorin (LV)/5-fluorouracil (5FU) or irinotecan (CPT-11) chemotherapy. Since 2003, we have generally administered LV and 5FU combined with CPT-11 (FOLFIRI) or oxaliplatin (FOLFOX). A resection of the primary tumor in the rectum or colon was performed in
Table II. Multivariate analysis of overall survival following the diagnosis of unresectable colorectal cancer with liver metastases.

\begin{tabular}{llc}
\hline Factor & Odds ratio $(95 \% \mathrm{CI})$ & $\mathrm{p}$-value \\
\hline $\begin{array}{l}\text { Primary tumor } \\
\text { resection }(\mathrm{No})\end{array}$ & $0.976(0.229-4.159)$ & 0.9738 \\
$\begin{array}{l}\text { Chemotherapy } \\
\text { for CRLM (No) }\end{array}$ & $4.016(1.098-14.683)$ & 0.0356 \\
$\begin{array}{l}\text { CEA } \\
(100 \mathrm{ng} / \mathrm{ml} \geq 100)\end{array}$ & $3.302(1.367-7.976)$ & 0.0079 \\
$\mathrm{CA} 19-9$ & $13.450(3.459-52.300)$ & 0.0002 \\
$(100 \mathrm{U} / \mathrm{ml} \geq 100)$ & & \\
\hline
\end{tabular}

CRLM, colorectal cancer with liver metastases; CEA, carcinoembryonic antigen; CA19-9, carbohydrate antigen 19-9; CI, confidence interval.

patients with a good performance status and in those with an intestinal obstruction.

The chemistry profile was routinely measured upon diagnosis of CRLM prior to systemic chemotherapy. The serum biochemistry data included serum aspartate aminotransferase (AST), alanine aminotransferase (ALT), total bilirubin (T-Bil) and tumor marker levels, including CEA and CA19-9. Serum CEA and CA19-9 were classified into the groups: $<100$ or $\geq 100 \mathrm{ng} / \mathrm{ml}$ and $<100$ or $\geq 100 \mathrm{U} / \mathrm{ml}$, respectively.

Firstly, using univariate and multivariate analyses, we investigated the correlation between patient characteristics and overall survival following the diagnosis of unresectable CRLM. Patient characteristics included age, gender, synchronous or metachronous CRLM, site of primary tumor (colon or rectum), presence or absence of primary tumor resection, primary tumor stage (II, III or IV) according to the International Union Against Cancer TNM classification (28), presence or absence of extrahepatic disease, presence or absence of systemic chemotherapy for CRLM, and serum CEA and CA19-9 levels.

We then compared patient characteristics of the CEA $<100$ and $\geq 100 \mathrm{ng} / \mathrm{ml}$ groups, as well as the CA19-9 $<100$ and $\geq 100 \mathrm{U} / \mathrm{ml}$ groups using the following parameters: age, gender, synchronous or metachronous CRLM, site of primary tumor, presence or absence of primary tumor resection, primary tumor stage, presence or absence of extrahepatic metastases, presence or absence of systemic chemotherapy for CRLM, and serum AST, ALT and T-Bil levels.

This study was approved by the Ethics Committee of Jikei University School of Medicine.

Statistical analysis. The data were presented as the means \pm standard deviation (SD). Univariate analysis was performed using the non-paired t-test and the Chi-square test. The analysis of overall survival was performed using the log-rank test. $\mathrm{P}<0.05$ was considered to indicate statistical significance.

\section{Results}

Univariate and multivariate analysis of overall survival following the diagnosis of unresectable CRLM and patient 
Table III. Univariate analysis of patient characteristics in relation to carcinoembryonic antigen upon diagnosis of unresectable colorectal cancer with liver metastases.

\begin{tabular}{|c|c|c|c|}
\hline \multirow[t]{2}{*}{ Characteristics } & \multicolumn{2}{|c|}{ CEA level } & \multirow[t]{2}{*}{ p-value } \\
\hline & $<100 \mathrm{ng} / \mathrm{ml}(\mathrm{n}=22)$ & $\geq 100 \mathrm{ng} / \mathrm{ml}(\mathrm{n}=18)$ & \\
\hline Age (years) & $68.8 \pm 9.9^{\mathrm{a}}$ & $62.8 \pm 10.4$ & 0.0716 \\
\hline Gender (male:female) & $17: 5$ & $13: 5$ & 0.7136 \\
\hline Timing of tumor (synchronous:metachronous) & $14: 8$ & $12: 6$ & 0.8416 \\
\hline Primary site (colon:rectum) & $12: 10$ & $11: 7$ & 0.6760 \\
\hline Primary tumor resection (yes:no) & $18: 4$ & $14: 4$ & 0.7506 \\
\hline Primary tumor stage (II, III:IV) & $6: 16$ & $28: 7$ & 0.9456 \\
\hline Extrahepatic disease (yes:no) & $12: 10$ & $12: 6$ & 0.4363 \\
\hline Chemotherapy for CRLM (yes:no) & $19: 3$ & $15: 3$ & 0.7895 \\
\hline $\operatorname{AST}(\mathrm{IU} / \mathrm{l})$ & $23.7 \pm 12.9$ & $37.2 \pm 26.7$ & 0.0613 \\
\hline $\operatorname{ALT}(\mathrm{IU} / 1)$ & $17.9 \pm 12.7$ & $28.9 \pm 31.3$ & 0.1748 \\
\hline Total-bilirubin (mg/dl) & $0.78 \pm 0.36$ & $0.91 \pm 1.02$ & 0.6181 \\
\hline
\end{tabular}

CRLM, colorectal cancer with liver metastases; CEA, carcinoembryonic antigen; AST, aspartate aminotransferase; ALT, alanine aminotransferase. ${ }^{\mathrm{a} M e a n} \pm \mathrm{SD}$.

Table IV. Univariate analysis of patients characteristics in relation to carbohydrate antigen 19-9 upon diagnosis of unresectable colorectal cancer with liver metastases.

\begin{tabular}{|c|c|c|c|}
\hline \multirow[t]{2}{*}{ Characteristics } & \multicolumn{2}{|c|}{ CA19-9 level } & \multirow[t]{2}{*}{ p-value } \\
\hline & $<100 \mathrm{U} / \mathrm{ml}(\mathrm{n}=30)$ & $\geq 100 \mathrm{U} / \mathrm{ml}(\mathrm{n}=10)$ & \\
\hline Age (years) & $66.3 \pm 9.3^{\mathrm{a}}$ & $65.5 \pm 13.7$ & 0.8362 \\
\hline Gender (male:female) & $23: 7$ & $7: 3$ & 0.6733 \\
\hline Timing of tumor (synchronous:metachronous) & $18: 12$ & $8: 2$ & 0.2508 \\
\hline Primary site (colon:rectum) & $18: 12$ & $5: 5$ & 0.5796 \\
\hline Primary tumor resection (yes:no) & $26: 4$ & $6: 4$ & 0.0679 \\
\hline Primary tumor stage (II, III:IV) & $10: 20$ & $1: 9$ & 0.1524 \\
\hline Extrahepatic disease (yes:no) & $18: 12$ & $8: 2$ & $>0.9999$ \\
\hline Chemotherapy for CRLM (yes:no) & $26: 4$ & $8: 2$ & 0.6091 \\
\hline $\operatorname{AST}(\mathrm{IU} / \mathrm{l})$ & $28.3 \pm 15.2$ & $34.4 \pm 34.0$ & 0.5930 \\
\hline $\operatorname{ALT}(\mathrm{IU} / \mathrm{l})$ & $20.6 \pm 12.2$ & $29.4 \pm 42.7$ & 0.5366 \\
\hline Total-bilirubin (mg/dl) & $0.73 \pm 0.34$ & $1.15 \pm 1.33$ & 0.3495 \\
\hline
\end{tabular}

CRLM, colorectal cancer with liver metastases; CA19-9, carbohydrate antigen 19-9; AST, aspartate aminotransferase; ALT, alanine aminotransferase. ${ }^{\mathrm{a} M e a n} \pm \mathrm{SD}$.

A

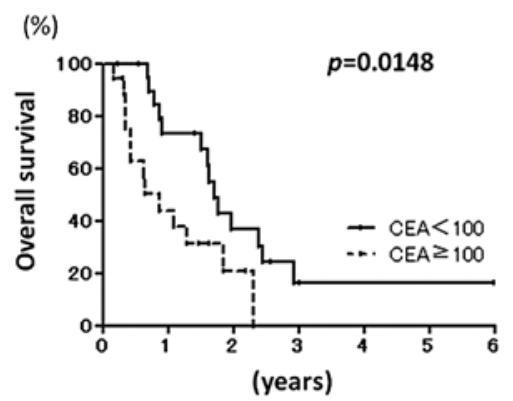

B

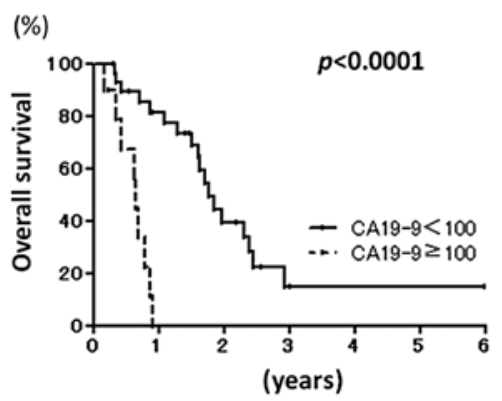

Figure 1. Kaplan-Meier curves of overall survival in patients with CEA $<100$ and CEA $\geq 100 \mathrm{ng} / \mathrm{ml}$ (A) and those with CA19-9 <100 and CA19-9 $\geq 100$ U/ml (B). CEA, carcinoembryonic antigen; CA19-9, carbohydrate antigen 19-9. 
characteristics. Table I shows the correlation between the patient characteristics and overall survival following the diagnosis of unresectable CRLM. In the univariate analysis, overall survival was significantly poorer in the case of absence of primary tumor resection ( $\mathrm{p}=0.0161)$, absence of systemic chemotherapy $(\mathrm{p}=0.0119)$, serum CEA level $\geq 100 \mathrm{ng} / \mathrm{ml}$ $(\mathrm{p}=0.0148$; Fig. 1A) and serum CA19-9 level $\geq 100 \mathrm{U} / \mathrm{ml}$ $(\mathrm{p}<0.0001$; Fig. 1B).

In the multivariate analysis, the significant factors from the univariate analysis were used, including the presence or absence of primary tumor resection, presence or absence of systemic chemotherapy, CEA level $<$ or $\geq 100 \mathrm{ng} / \mathrm{ml}$, and CA19-9 level $<$ or $\geq 100 \mathrm{U} / \mathrm{ml}$. The absence of systemic chemotherapy ( $\mathrm{p}=0.0356)$, CEA level $\geq 100 \mathrm{ng} / \mathrm{ml}(\mathrm{p}=0.0079)$ and CA19-9 level $\geq 100 \mathrm{U} / \mathrm{ml}(\mathrm{p}=0.0002)$ were found to be independent and significant predictors of overall survival (Table II).

Univariate analysis of patient characteristics in relation to serum CEA levels upon diagnosis of unresectable CRLM. Table III shows the correlation between patient characteristics and serum CEA levels. Univariate analysis demonstrated that all factors in both the CEA $<100$ and CEA $\geq 100 \mathrm{ng} / \mathrm{ml}$ groups were comparable.

Univariate analysis of patients characteristics in relation to serum CA19-9 levels upon diagnosis of unresectable CRLM. Table IV shows the correlation between patient characteristics and serum CA19-9 levels. Univariate analysis demonstrated that all factors in both the CA19-9 $<100$ and the CA19-9 $\geq 100 \mathrm{U} / \mathrm{ml}$ groups were comparable.

\section{Discussion}

Since 20 to $30 \%$ of patients with colorectal cancer have synchronous or metachronous liver metastases, their management is a common and significant clinical problem. Several studies have discussed the predictors of long-term survival in patients with CRLM. Jaeck et al reported that three factors, serosa infiltration, involvement of peritumoral lymph nodes around the primary colorectal tumor and a liver resection margin of less than $1 \mathrm{~cm}$, proved to be independently significant by multivariate analysis (29). Minagawa et al reported that the stage of the primary tumor (III or IV), lymph node metastasis and multiple nodules were significantly associated with a poor prognosis in multivariate analysis (10). In the present study, absence of systemic chemotherapy, serum CEA level $\geq 100 \mathrm{ng} / \mathrm{ml}$ and serum CA19-9 level $\geq 100 \mathrm{U} / \mathrm{ml}$ were independent significant predictors in patients with unresectable CRLM by multivariate analysis.

The preoperative level of tumor markers was also reported to be a predictive factor of survival in patients with CRLM. Adam et al reported that high preoperative levels of serum CEA $(\geq 30 \mathrm{ng} / \mathrm{ml})$ and CA19-9 $(\geq 100 \mathrm{U} / \mathrm{ml})$ were poorer predictors of poor survival following liver resection (30). Ishizuka et al reported that the preoperative serum CEA level $(\geq 150 \mathrm{ng} / \mathrm{ml}$ ) and CA19-9 level ( $\geq 200 \mathrm{U} / \mathrm{ml}$ ) were significant predictors of poor survival in patients with CLRM (31). For unresectable CLRM, Hotta et al reported that a $>1.0$ ratio of postoperative/preoperative CEA was a factor of poor prog- nosis in multivariate analysis (32). However, no evidence is available demonstrating the prognostic value of serum CEA and CA19-9 levels in patients with unresectable CRLM. In this study, we demonstrated that serum CEA $(\geq 100 \mathrm{ng} / \mathrm{ml})$ and CA19-9 levels ( $\geq 100 \mathrm{U} / \mathrm{ml})$ were significant and independent predictors of poor survival in patients with unresectable CLRM by multivariate analysis. Recent chemotherapy regimens, including LV and 5FU combined with CPT-11 or oxaliplatin, have demonstrated survival benefits in patients with advanced colorectal cancer including unresectable liver metastasis (33-36). Therefore, the measurement of serum CEA and CA19-9 prior to treatment including both hepatectomy and chemotherapy for CRLM may provide a prognostic indicator, and contribute to advances in therapeutic strategy.

In conclusion, the serum CEA and CA19-9 levels upon diagnosis of unresectable CLRM were independent and significant predictors of overall survival. The measurement of serum CEA and CA19-9 levels may aid in improving the management of patients with CLRM.

\section{References}

1. Weitz J, Koch M, Debus J, Höhler T, Galle PR and Büchler MW: Colorectal cancer. Lancet 365: 153-65, 2005.

2. O'Reilly DA and Poston GJ: Colorectal liver metastases: current and future perspectives. Future Oncol 2: 525-531, 2006.

3. Rodgers MS and McCall JL: Surgery for colorectal liver metastases with hepatic lymph node involvement: a systematic review. Br J Surg 87: 1142-1155, 2000.

4. Martin LW and Warren RS: Current management of colorectal liver metastases. Surg Oncol Clin N Am 9: 853-876, 2000.

5. Penna $\mathrm{C}$ and Nordlinger B: Colorectal metastasis (liver and lung). Surg Clin North Am 82: 1075-1090, 2002.

6. Kato T, Yasui K, Hirai T, Kanemitsu Y, Mori T, Sugihara K, Mochizuki H, and Yamamoto J: Therapeutic results for hepatic metastasis of colorectal cancer with special reference to effectiveness of hepatectomy: analysis of prognostic factors for 763 cases recorded at 18 institutions. Dis Colon Rectum 46: S22-S31, 2003.

7. Nordlinger B, Guiguet M, Vaillant JC, Balladur P, Boudjema K, Bachellier P and Jaeck D: Surgical resection of colorectal carcinoma metastases to the liver. A prognostic scoring system to improve case selection, based on 1568 patients. Cancer 77 : 1254-1262, 1996.

8. Seifert JK, Böttger TC, Weigel TF, Gönner U and Junginger T: Prognostic factors following liver resection for hepatic metastases from colorectal cancer. Hepatogastroenterology 47: 239-246, 2000.

9. Fong Y, Fortner J, Sun RL, Brennan MF and Blumgart LH: Clinical score for predicting recurrence after hepatic resection for metastatic colorectal cancer: analysis of 1001 consecutive cases. Ann Surg 230: 309-321, 1999.

10. Minagawa M, Makuuchi M, Torzilli G, Takayama T, Kawasaki S, Kosuge T, Yamamoto $\mathrm{J}$ and Imamura $\mathrm{H}$ : Extension of the frontiers of surgical indications in the treatment of liver metastases from colorectal cancer: long-term results. Ann Surg 231: 487-499, 2000.

11. Jonas S, Thelen A, Benckert C, Spinelli A, Sammain S, Neumann U, Rudolph B and Neuhaus P: Extended resections of liver metastases from colorectal cancer. World J Surg 31: 511-521, 2007.

12. Jaeck D, Oussoultzoglou E, Rosso E, Greget M, Weber JC and Bachellier P: A two-stage hepatectomy procedure combined with portal vein embolization to achieve curative resection for initially unresectable multiple and bilobar colorectal liver metastases. Ann Surg 240: 1037-1049, 2004.

13. Wood CB, Gillis CR and Blumgart LH: A retrospective study of the natural history of patients with liver metastases from colorectal cancer. Clin Oncol 2: 285-288, 1976.

14. Wagner JS, Adson MA, Van Heerden JA, Adson MH and Ilstrup DM: The natural history of hepatic metastases from colorectal cancer: a comparison with resective treatment. Ann Surg 199: 502-508, 1984. 
15. Wanebo HJ, Rao B, Pinsky CM, Hoffman RG, Stearns M, Schwartz MK and Oettgen HF: Preoperative carcinoembryonic antigen level as a prognostic indicator in colorectal cancer. N Engl J Med 299: 448-451, 1978.

16. Moertel CG, O'Fallon JR, Go VL, O'Connell MJ and Thynne GS: The preoperative carcinoembryonic antigen test in the diagnosis, staging, and prognosis of colorectal cancer. Cancer 58: 603-610, 1986.

17. Zamcheck N: The present status of CEA in diagnosis, prognosis, and evaluation of therapy. Cancer 36: 2460-2468, 1975.

18. Martin EW Jr, James KK, Hurtubise PE, Catalano P and Minton JP: The use of CEA as an early indicator for gastrointestinal tumor recurrence and second-look procedures. Cancer 39: 440-446, 1977.

19. Cooper MJ, Mackie CR, Skinner DB and Moossa AR: A reappraisal of the value of carcinoembryonic antigen in the management of patients with various neoplasms. Br J Surg 66 120-123, 1979 .

20. Steele G Jr, Ellenberg S, Ramming K, O'Connell M, Moertel C, Lessner H, Bruckner H, Horton J, Schein P, Zamcheck N, Novak $J$ and Holyoke ED: CEA monitoring among patients in multi-institutional adjuvant G.I. therapy protocols. Ann Surg 196: 162-169, 1982.

21. Barillari P, Ramacciato G, de Angelis R, Gozzo P, Aurello P, Indinnimeo M, Valabrega S, D'Angelo F and Fegiz G: The role of CEA, TPA and CA 19-9 in the early detection of recurrent colorectal cancer. Int J Colorectal Dis 4: 230-233, 1989.

22. Koprowski H, Herlyn M, Steplewski Z and Sears HF: Specific antigen in serum of patients with colon carcinoma. Science 212 53-55, 1981.

23. Kuusela P, Jalanko H, Roberts P, Sipponen P, Mecklin JP, Pitkänen R and Mäkelä O: Comparison of CA 19-9 and carcinoembryonic antigen (CEA) levels in the serum of patients with colorectal diseases. Br J Cancer 49: 135-139, 1984.

24. Filella X, Molina R, Grau JJ, Piqué JM, Garcia-Valdecasas JC, Astudillo E, Biete A, Bordas JM, Novell A, Campo E and Ballesta AM: Prognostic value of CA 19.9 levels in colorectal cancer. Ann Surg 216: 55-59, 1992.

25. Kouri M, Pyrhönen S and Kuusela P: Elevated CA19-9 as the most significant prognostic factor in advanced colorectal carcinoma. J Surg Oncol 49: 78-85, 1992.

26. Nakayama T, Watanabe M, Teramoto T and Kitajima M: CA19-9 as a predictor of recurrence in patients with colorectal cancer. J Surg Oncol 66: 238-243, 1997.
27. Japanese Society for Cancer of the Colon and Rectum: Japanese classification of colorectal carcinoma. 1st English edition. Kanehara Co., Ltd., Tokyo, 1997.

28. Sobin LH and Wittekind CH: UICC TNM classification of malignant tumors. 5th edition. John Wiley \& Sons, Inc., New York, 1997.

29. Jaeck D, Bachellier P, Guiguet M, Boudjema K, Vaillant JC, Balladur P and Nordlinger B: Long-term survival following resection of colorectal hepatic metastases. Association Française de Chirurgie. Br J Surg 84: 977-980, 1997.

30. Adam R, Delvart V, Pascal G, Valeanu A, Castaing D, Azoulay D, Giacchetti S, Paule B, Kunstlinger F, Ghémard O, Levi F and Bismuth H: Rescue surgery for unresectable colorectal liver metastases downstaged by chemotherapy: a model to predict long-term survival. Ann Surg 240: 644-658, 2004.

31. Ishizuka D, Shirai Y, Sakai Y and Hatakeyama K: Colorectal carcinoma liver metastases: clinical significance of preoperative measurement of serum carcinoembryonic antigen and carbohydrate antigen 19-9 levels. Int J Colorectal Dis 16: 32-37, 2001.

32. Hotta T, Takifuji K, Uchiyama K, Yokoyama S, Matsuda K, Higashiguchi T, Tominaga T, Oku Y, Nasu T and Yamaue H: Potential predictors of survival after surgery for colorectal cancer patients with synchronous unresectable liver metastases. Oncol Rep 16: 1369-1374, 2006.

33. Saltz LB, Cox JV, Blanke C, Rosen LS, Fehrenbacher L, Moore MJ, Maroun JA, Ackland SP, Locker PK, Pirotta N, Elfring GL and Miller LL: Irinotecan plus fluorouracil and leucovorin for metastatic colorectal cancer. Irinotecan Study Group. N Engl J Med 343: 905-914, 2000

34. Douillard JY, Cunningham D, Roth AD, Navarro M, James RD, Karasek P, Jandik P, Iveson T, Carmichael J, Alakl M, Gruia G, Awad L and Rougier P: Irinotecan combined with fluorouracil compared with fluorouracil alone as first-line treatment for metastatic colorectal cancer: a multicentre randomised trial. Lancet 355: 1041-1047, 2000.

35. De Gramont A, Vignoud J, Tournigand C, Louvet C, André T, Varette C, Raymond E, Moreau S, Le Bail N and Krulik M: Oxaliplatin with high-dose leucovorin and 5-fluorouracil 48-hour continuous infusion in pretreated metastatic colorectal cancer. Eur J Cancer 33: 214-219, 1997.

36. Poston GJ: The use of irinotecan and oxaliplatin in the treatment of advanced colorectal cancer. Eur J Surg Oncol 31: 325-330, 2005. 